\title{
A Study on Learning Style of Higher Secondary School Students
}

\section{OPEN ACCESS}

Manuscript ID:

EDU-2020-09013389

Volume: 9

Issue: 1

Month: December

Year: 2020

P-ISSN: 2320-2653

E-ISSN: 2582-1334

Received: 22.08 .2020

Accepted: 30.10 .2020

Published: 01.12.2020

Citation:

Udhaya Mohan Babu, R., and G. Kalaiyarasan. "A Study on Learning Style of Higher Secondary School Students." Shanlax International Journal of Education, vol. 9, no. 1, 2020, pp. 163-168.

DOI:

https://doi.org/10.34293/ education.v9i1.3389

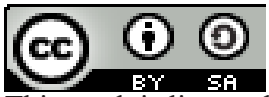

This work is licensed under a Creative Commons Attribution-ShareAlike 4.0 International License

\section{R. Udhaya Mohan Babu}

UGC-Senior Research Fellow, Department of Education

Alagappa University, Karaikudi, Tamil Nadu, India

D https://orcid.org/0000-0002-0137-3955

\section{G. Kalaiyarasan}

Professor \& Head, Department of Education

Alagappa University, Karaikudi, Tamil Nadu, India

\section{Abstract}

The author has investigated the learning style of the students and behavioral change in the learner and also when they note the persistence of this change. Learning happens in stages, and at each stage, students learn in different ways. Difficulties that arise at home, schooling are often due to differences in learning styles. It has been proposed that teachers should assess the learning styles of their students and adapt their classroom methods to best fit each student's learning style. These possessed learning styles play a vital role in deciding their level of achievement. This achieved test score determines their future career. The ambitions and aspirations of our students are largely governed by their learning skills adopted by the students. There is no significant difference between $X I$ and XII standard higher secondary school students in their learning styles in the dimensions. This study will be more fruitful when suggestions given by the investigator are applied for further study and it will be of great help for those who want to study further in this field.

Keywords: Learning style, Higher secondary school students

\section{Introduction}

Learning happens inside an individual's heads in the mind, and it is a tremendously multifaceted and complex procedure. Information about learning can be gathered by logical techniques when such information is satisfactorily checked, it tends to be communicated as learning standards. Learning is a procedure, which empowers the educator to perceive that learning has occurred when they note a conduct change in the student and when they note the steadiness of this change. Learning occurs in stages, and at each stage, understudies learn in various manners. Troubles that emerge in-home tutoring are frequently because of contrasts in learning styles.

\section{Review of Related Literature}

Cox, D.E. et al., (1988). Learning style assortments among common and urban understudies. Learning styles of auxiliary school understudies vary among solitary understudies and social occasions of understudies. As a general rule, differentiation in learning exists in the current homerooms. In any case, instances of dreary and solid learning conduct in the examination corridor may in like manner, be viewed. For example, certain understudies become adequately connected with verbalizing examinations, while others favor handson experiences. Still, others appear to the teacher to idly hold their condition. Such planned practices are typical for principal styles of learning. 
K. Karthigeyan and K. Nirmala (2013). Learning Style Preference of English Language Learners. In the current time frame, one of the most critical issues in the understudy centered scholastic setting is the learning approach of the understudies, which joins the changed learning style tendency of the individuals in any language learning. Learning styles are inherent tendencies of individuals concerning how they need to move toward the path toward learning and it is one of the prevalent factors which impact the academic accomplishment of understudies. The inspiration driving the current assessment is to perceive the predominant learning style tendency of English language understudies in higher discretionary schools concerning section factors like sexual direction, area, nature of instructive board of trustees and class in which they are mulling over. The Perceptual Learning Style Preference Questionnaire (PLSPQ) made by Joy Reid was balanced by the master and the faithful nature of the review was set up. The overview was coordinated to 582 understudies. The data were analyzed using illustrative and rate assessments. Data examination exhibited that the fundamental and helper learning styles of the understudies were visual and hear-capable learning styles.

\section{Learning Styles}

Learning styles are, in its least complex structure, approaches or methods of learning. It includes learning techniques that are dared to permit that person to learn best. It is regularly accepted that many people favor some specific techniques for associating with, taking in, and preparing improvements or data. Individualized learning styles started during the 1970s. It has picked up prevalence as of late, given this idea. It has been recommended that educators ought to evaluate the learning styles of their understudies and adjust their study hall techniques to best fit every understudy's learning style.

Learning styles is a general term covering a range of modalities, inclinations and procedures by which individual ingest, process and react to circumstances and info bringing about learning. Learning style is characterized as "the perplexing way where and conditions under which students most proficiently and most adequately see the procedure, store, and review what they are endeavoring to learn."

\section{Significance of the Study}

Learning styles is a significant factor in the Academic accomplishment of the understudies. A few understudies have great learning styles, a few understudies may have helpless learning styles which might be because of a few factors, for example, family foundations, financial status, size of the family, training of the guardians. Singular contrasts additionally assume a crucial job in the learning styles of kids. Taking in styles might be not the same as a youngster to the kid and they likewise vary if there should arise an occurrence of high, normal and low achievers. What's more, the learning styles likewise shift among the understudies from school to class, the executives to the board, region to-area. In our present cultural arrangement, school fills in as one significant instrument in bestowing information. It has gotten compulsory and commitment for the guardians and the legislature to instruct all youngsters in our country. In this situation, no kid is qualified to lose the benefit of concentrating in a school. All school participants, from start to finish, require a few styles and practice them to effectively seek information. These had learning styles assume a fundamental job in choosing their degree of accomplishment. This accomplished grade decides their future vocation. The desire and yearnings of our understudies are generally represented by their learning aptitudes embraced by the understudies.

\section{Objectives}

To find out the significant difference in the learning styles and its dimensions of higher school students concerning background variables such as class, sex, type of school.

\section{Hypotheses}

- There is no significant difference between XI and XII standard higher secondary school students in their learning styles and dimensions.

- There is no significant difference between male and female standard higher secondary school students in their learning styles and dimensions.

- There is no significant difference among government, aided, self-finance rural standard higher secondary school students in their learning styles and their dimensions. 


\section{Method Adopted in the Present Study}

The survey method is selected for the present study. Survey research deals with the incidence, distribution and relationships of educational and sociological variables. The survey is a procedure in which data were systematically collected from a population through some direct solicitations such as face-to-face interviews, questionnaires or schedules, observation.

\section{Tools Used in the Present Study}

The investigator used the following tools for collecting data that were very useful for fulfilling various objectives of his study.
- General Data Sheet

- Learning Styles Scale

\section{The population of the Study}

The population of the study consists of higher secondary students. The investigator has used a stratified random sampling technique. 125 students are randomly selected from different schools.

\section{Hypotheses Testing \\ Null Hypothesis: 1}

There is no significant difference between XI and XII standard higher secondary school students in their learning styles and their dimensions.

Table 1: Difference Between XI and XII Standard Higher Secondary School Students in their Learning Styles and their Dimensions

\begin{tabular}{|c|c|c|c|c|c|c|}
\hline Dimensions & Category & $\mathbf{N}$ & Mean & S.D & Calculated 't' Value & Remark at 5\% Level \\
\hline \multirow{2}{*}{ a) Linguistic } & $\mathrm{XI}$ & 51 & 31.35 & 4.41 & \multirow{2}{*}{0.09} & \multirow{2}{*}{ NS } \\
\hline & XII & 74 & 31.28 & 4.25 & & \\
\hline \multirow{2}{*}{ b) Logical } & $\mathrm{XI}$ & 51 & 28.31 & 4.49 & \multirow{2}{*}{1.40} & \multirow{2}{*}{ NS } \\
\hline & XII & 74 & 27.18 & 4.42 & & \\
\hline \multirow{2}{*}{ c) Spatial } & $\mathrm{XI}$ & 51 & 19.90 & 3.49 & \multirow{2}{*}{0.59} & \multirow{2}{*}{ NS } \\
\hline & $\mathrm{XII}$ & 74 & 19.54 & 3.11 & & \\
\hline \multirow{2}{*}{ d) Musical } & $\mathrm{XI}$ & 51 & 23.86 & 4.27 & \multirow{2}{*}{0.55} & \multirow{2}{*}{ NS } \\
\hline & XII & 74 & 23.43 & 4.30 & & \\
\hline \multirow{2}{*}{ e) Bodily Kinesthetic } & $\mathrm{XI}$ & 51 & 14.51 & 2.49 & \multirow{2}{*}{2.20} & \multirow{2}{*}{$\mathrm{S}$} \\
\hline & $\mathrm{XII}$ & 74 & 13.45 & 2.89 & & \\
\hline \multirow{2}{*}{ f) Interpersonal } & $\mathrm{XI}$ & 51 & 21.73 & 4.16 & \multirow{2}{*}{1.37} & \multirow{2}{*}{ NS } \\
\hline & XII & 74 & 20.68 & 4.30 & & \\
\hline \multirow{2}{*}{ g) Learning Styles } & $\mathrm{XI}$ & 51 & 139.67 & 16.60 & \multirow{2}{*}{1.32} & \multirow{2}{*}{ NS } \\
\hline & XII & 74 & 135.59 & 17.47 & & \\
\hline
\end{tabular}

(At $5 \%$ level of significance, the table value for $123 \mathrm{df}$ is 1.98 )

Since the calculated ' $t$ ' value is less than the table value for 123 degrees of freedom, there is no significant difference between XI and XII standard higher secondary school students in their learning styles and its dimensions - linguistic, logical, spatial, musical, interpersonal, learning styles. Since the calculated ' $t$ ' value is greater than the table value for 123 degrees of freedom, there is a significant difference between XI and XII standard higher secondary school students in their learning styles and its dimension - bodily-kinesthetic.

\section{Null Hypothesis: 2}

There is no significant difference between male and female higher secondary school students in their learning styles and their dimensions. 
Table 2: Difference Between Male and Female Higher Secondary

School Students in their Learning Styles and their Dimensions

\begin{tabular}{|c|c|c|c|c|c|c|}
\hline Dimensions & Category & $\mathbf{N}$ & Mean & S.D & Calculated 't' Value & Remark at 5\% Level \\
\hline \multirow{2}{*}{ a) Linguistic } & Male & 64 & 30.64 & 4.31 & \multirow{2}{*}{1.81} & \multirow{2}{*}{ NS } \\
\hline & Female & 61 & 32.02 & 4.21 & & \\
\hline \multirow{2}{*}{ b) Logical } & Male & 64 & 27.52 & 3.80 & \multirow{2}{*}{0.32} & \multirow{2}{*}{ NS } \\
\hline & Female & 61 & 27.77 & 5.09 & & \\
\hline \multirow{2}{*}{ c) Spatial } & Male & 64 & 19.80 & 3.14 & \multirow{2}{*}{0.38} & \multirow{2}{*}{ NS } \\
\hline & Female & 61 & 19.57 & 3.41 & & \\
\hline \multirow{2}{*}{ d) Musical } & Male & 64 & 23.42 & 4.44 & \multirow{2}{*}{0.50} & \multirow{2}{*}{ NS } \\
\hline & Female & 61 & 23.80 & 4.12 & & \\
\hline \multirow{2}{*}{ e) Bodily Kinesthetic } & Male & 64 & 13.58 & 2.60 & \multirow{2}{*}{1.25} & \multirow{2}{*}{ NS } \\
\hline & Female & 61 & 14.20 & 2.94 & & \\
\hline \multirow{2}{*}{ f) Interpersonal } & Male & 64 & 20.30 & 4.00 & \multirow{2}{*}{1.86} & \multirow{2}{*}{ NS } \\
\hline & Female & 61 & 21.95 & 4.39 & & \\
\hline \multirow{2}{*}{ g) Learning Styles } & Male & 64 & 135.25 & 16.49 & \multirow{2}{*}{1.34} & \multirow{2}{*}{ NS } \\
\hline & Female & 61 & 139.36 & 17.76 & & \\
\hline
\end{tabular}

(At $5 \%$ level of significance, the table value for $123 \mathrm{df}$ is 1.98 )

Since the calculated ' $t$ ' value is less than the table value for 123 degrees of freedom, there is no significant difference between male and female standard higher secondary school students in their learning styles and its dimensions - linguistic, logical, spatial, musical, bodily-kinesthetic, interpersonal, learning styles.

Table 3: Difference among Government, Aided, Self-Finance Higher Secondary School Students in their Learning Styles and their Dimensions

\begin{tabular}{|c|c|c|c|c|c|c|}
\hline Dimensions & $\begin{array}{l}\text { Source of } \\
\text { Variation }\end{array}$ & $\begin{array}{l}\text { Sum of } \\
\text { Squares }\end{array}$ & $\begin{array}{c}\text { Mean Square } \\
\text { Variance }\end{array}$ & $\begin{array}{c}\text { Degrees of } \\
\text { Freedom }\end{array}$ & $\begin{array}{l}\text { Calculated } \\
\text { 'F' Value }\end{array}$ & $\begin{array}{c}\text { Remark at } \\
5 \% \text { Level }\end{array}$ \\
\hline \multirow{2}{*}{ a) Linguistic } & Between & 168.30 & 84.15 & 2 & \multirow{2}{*}{4.76} & \multirow{2}{*}{$\mathrm{S}$} \\
\hline & Within & 2158.53 & 17.69 & 122 & & \\
\hline \multirow{2}{*}{ b) Logical } & Between & 38.74 & 19.37 & 2 & \multirow{2}{*}{0.96} & \multirow{2}{*}{ NS } \\
\hline & Within & 2472.05 & 20.26 & 122 & & \\
\hline \multirow{2}{*}{ c) Spatial } & Between & 14.43 & 7.22 & 2 & \multirow{2}{*}{0.66} & \multirow{2}{*}{ NS } \\
\hline & Within & 1326.40 & 10.87 & 122 & & \\
\hline \multirow{2}{*}{ d) Musical } & Between & 4.14 & 2.07 & 2 & \multirow{2}{*}{0.11} & \multirow{2}{*}{ NS } \\
\hline & Within & 2297.65 & 18.83 & 122 & & \\
\hline \multirow{2}{*}{ e) Bodily-Kinesthetic } & Between & 36.24 & 18.12 & 2 & \multirow{2}{*}{2.37} & \multirow{2}{*}{ NS } \\
\hline & Within & 932.96 & 7.65 & 122 & & \\
\hline \multirow{2}{*}{ f) Interpersonal } & Between & 88.37 & 44.18 & 2 & \multirow{2}{*}{2.45} & \multirow{2}{*}{ NS } \\
\hline & Within & 2199.28 & 18.03 & 122 & & \\
\hline \multirow{2}{*}{ g) Learning Styles } & Between & 1132.50 & 566.25 & 2 & \multirow{2}{*}{1.92} & \multirow{2}{*}{ NS } \\
\hline & Within & 36025.25 & 295.29 & 122 & & \\
\hline
\end{tabular}

(At $5 \%$ level of significance, the table ' $\mathrm{f}$ ' value for $(2,122) \mathrm{df}$ is 3.07 )
There is no significant difference among government, aided, self-financed higher secondary school students in their learning styles and dimensions. 
It is inferred from the above table that the calculated ' $\mathrm{f}$ ' value $\mathrm{b}, \mathrm{c}, \mathrm{d}, \mathrm{e}, \mathrm{f}, \mathrm{g}$ are less than the table value $(3.07)$ for $(2,122)$ degrees of freedom at $5 \%$ level of significance, hence the null hypotheses $\mathrm{b}, \mathrm{c}, \mathrm{d}, \mathrm{e}, \mathrm{f}, \mathrm{g}$ is accepted. It is inferred from the above table that the calculated ' $\mathrm{f}$ ' value $\mathrm{a}$ is greater than the table value $(3.07)$ for $(2,122)$ degrees of freedom at a $5 \%$ level of significance. Hence the null hypothesis is rejected.

\section{Results and Findings}

Since the calculated't' value is less than the table value for 123 degrees of freedom, there is no significant difference between XI and XII standard higher secondary school students in their learning styles and its dimensions - linguistic, logical, spatial, musical, interpersonal, learning styles. Since the calculated ' $t$ ' value is greater than the table value for 123 degrees of freedom, there is a significant difference between XI and XII standard higher secondary school students in their learning styles and its dimension - bodily-kinesthetic.

Since the calculated ' $t$ ' value is less than the table value for 123 degrees of freedom, there is no significant difference between male and female standard higher secondary school students in their learning styles and its dimensions - linguistic, logical, spatial, musical, bodily-kinesthetic, interpersonal, learning styles.

It is inferred from the above table that the calculated ' $\mathrm{f}$ ' value $\mathrm{b}, \mathrm{c}, \mathrm{d}, \mathrm{e}, \mathrm{f}, \mathrm{g}$ are less than the table value $(3.07)$ for $(2,122)$ degrees of freedom at $5 \%$ level of significance, hence the null hypotheses $\mathrm{b}, \mathrm{c}, \mathrm{d}, \mathrm{e}, \mathrm{f}, \mathrm{g}$ is accepted. It is inferred from the above table that the calculated ' $\mathrm{f}$ ' value a is greater than the table value $(3.07)$ for $(2,122)$ degrees of freedom at a $5 \%$ level of significance, hence the null hypothesis is rejected.

\section{Conclusion}

Even though there are some limitations in the present study, it is evident that the learning styles of rural and urban high school students are average. The former president of India Dr. A.P.J. Abdul Kalam expresses his faith in youths who would contribute the national development. The recommendations given by the investigator may be very helpful for improving the learning styles of the students. This study will be more fruitful when suggestions given by the investigator are applied for further study and it will be of great help for those who want to study further in this field.

\section{References}

Babu, R. U.M., and G. Kalaiyarasan. "Integrating Technology in Teaching and Teacher Education." International Journal of Multidisciplinary Educational Research, vol. 6, no. 3, 2017.

Babu, R.U.M., and G. Kalaiyarasan. "New Education Policy Consultation." Pros and Cons of New Educational Policy, 2019.

Bostrom, Robert P., et al. "The Importance of Learning Style in End-User Training." MIS Quarterly, vol. 14, no. 1, 1990, pp. 101-119.

Brown, Bettina Lankard. "Teaching Style vs. Learning Style." Myths and Realities, no. 26, 2003.

Busato, Vittorio V., et al. "Intellectual Ability, Learning Style, Personality, Achievement Motivation and Academic Success of Psychology Students in Higher Education." Personality and Individual Differences, vol. 29, no. 6, 2000, pp. 1057-1068.

Cassidy, Simon, and Peter Eachus. "Learning Style, Academic Belief Systems, Self-Report Student Proficiency and Academic Achievement in Higher Education." Educational Psychology, vol. 20, no. 3, 2000, pp. 307-322.

Dunn, Rita. How to Implement and Supervise a Learning Style Program, Association for Supervision and Curriculum Development, 1996.

Dunn, Rita. "Learning Style: State of the Science." Theory into Practice, vol. 23, no. 1, 1984, pp. 10-19.

Furnham, Adrian, et al. "Personality, Learning Style, and Work Performance." Personality and Individual Differences, vol. 27, no. 6, 1999, pp. 1113-1122.

Furnham, Adrian. "Personality and Learning Style: A Study of Three Instruments." Personality and Individual Differences, vol. 13, no. 4, 1992, pp. 429-438. 
Hawk, Thomas F., and Amit J. Shah. "Using Learning Style Instruments to Enhance Student Learning." Decision Sciences Journal of Innovative Education, vol. 5, no. 1, 2007, pp. 1-19.

Keefe, James W. Learning Style: Cognitive and Thinking Skills, National Association of Secondary School Principals, 1991.

Keefe, James W. Learning Style: Theory and Practice, National Association of Secondary School Principals, 1987.

Keefe, James W. Profiling and Utilizing Learning Style, National Association of Secondary School Principals, 1988.

Kirby, Patricia. Cognitive Style, Learning Style, and Transfer Skill Acquisition, National Center for Research in Vocational Education, Ohio State University, 1979.

Klašnja-Milićević, Aleksandra, et al. "E-Learning Personalization based on Hybrid Recommendation Strategy and Learning Style Identification." Computers \& Education, vol. 56, no. 3, 2011, pp. 885-899.

Kolb, David A. The Kolb Learning Style Inventory, Hay Resources Direct, 2005.

Kolb, David A. "Experiential Learning Theory and the Learning Style Inventory: A Reply to Freedman and Stumpf." Academy of Management Review, vol. 6, no. 2, 1981, pp. 289-296.

Ladd, Paula D., and Ralph Ruby Jr. "Learning Style and Adjustment Issues of International Students." Journal of Education for Business, vol. 74, no. 6, 1999, pp. 363-367.

$\mathrm{Lu}$, June, et al. "Learning Style, Learning Patterns, and Learning Performance in a WebCT-based MIS Course." Information \& Management, vol. 40, no. 6, 2003, pp. 497-507.
Lynch, Thomas G., et al. "Learning Style Influences Student Examination Performance." The American Journal of Surgery, vol. 176, no. 1, 1998, pp. 62-66.

Neuhauser, Charlotte. "Learning Style and Effectiveness of Online and Face-to-Face Instruction." The American Journal of Distance Education, vol. 16, no. 2, 2002, pp. 99-113.

Pask, Gordon. "Learning Strategies, Teaching Strategies, and Conceptual or Learning Style." Learning Strategies and Learning Styles, edited by Ronald Ray Schmeck, Springer, 1988, pp. 83-100.

Peterson, Elizabeth R., et al. "Researching the Psychology of Cognitive Style and Learning Style: Is there Really a Future?." Learning and Individual Differences, vol. 19, no. 4, 2009, pp. 518-523.

Price, Linda. "Individual Differences in Learning: Cognitive Control, Cognitive Style, and Learning Style." Educational Psychology, vol. 24, no. 5, 2004, pp. 681-698.

Reid, Joy M. Learning Styles in the ESL/EFL Classroom, Heinle \& Heinle Publishers, 1995.

Reid, Joy M. "The Learning Style Preferences of ESL Students." TESOL Quarterly, vol. 21, no. 1, 1987, pp. 87-111.

Sadler-Smith, Eugene. "The Relationship between Learning Style and Cognitive Style." Personality and Individual Differences, vol. 30, no. 4, 2001, pp. 609-616.

Sadler-Smith, Eugene. "Learning Style': Frameworks and Instruments." Educational Psychology, vol. 17, no. 1-2, 1997, pp. 51-63.

\section{Author Details}

R. Udhaya Mohan Babu, UGC-Senior Research Fellow, Department of Education, Alagappa University, Karaikudi, Tamil Nadu, India, Email ID: Mohaneducation.1990@gmail.com.

Dr. G. Kalaiyarasan, Professor \& Head, Department of Education, Alagappa University, Karaikudi, Tamil Nadu, India. 